\title{
STUDY ON THE CONTAMINATION OF FINE GRAINED SOIL WITH MOLASSES DESUGARIZATION LIQUID INDUSTRIAL WASTE (CASE STUDY)
}

\author{
Shawky M. Hussein*, El-Sharif M. Abdel-Aziz**, \\ Sayida R. Zeedan ${ }^{* * *}$ and Yehya K. Taha** \\ * Civil Eng. Egyptian Sugar \& Integrated industries Co., Edfu Factories \\ ** Civil Eng Dept., Faculty of Eng, Assiut University. \\ *** Housing \& Building National Research Centre " Raw Material and \\ Processing Institute"
}

(Received March 27, 2008 Accepted May 13, 2008)

The main problem presented in this paper arises from the acidic impact of the diluted venasis of the "Liquid industrial waste resulting from molasses desugarization" (LIWMD) at refinement factories. This liquid waste emerges through large areas around the reservoirs and spreads into the soil due to the presence of any defect in the tanks and connecting pipes. The (LIWMD) flows through the soil around or under foundations, and with time, reach deep distances into the soil causing many problems. The purpose of this research is to study the effect of (LIWMD) contamination on the physical and mechanical properties of fine grained soil. These properties were determined in the laboratory before and after mixing the soil with the (LIWMD). The results show that the (LIWMD) contamination has significant effect on the soil cohesion. The angle of internal friction also decreases with the increase of the percentage of liquid waste beyond 15\%. Also, it has been found that coefficients of consolidation, volume change and permeability decreases with the increase of the amount of liquid waste in the soil.

\begin{tabular}{|c|c|c|c|}
\hline \multicolumn{4}{|c|}{ NOTATION } \\
\hline LIWMD & Industrial waste liquid from & $\mathrm{Sc}$ & settlement of consolidation \\
\hline & molasses desugarization & $\gamma_{\mathrm{dmax}}$ & maximum dry density, $\mathrm{t} / \mathrm{m}^{3}$ \\
\hline$\varphi$ & angle of internal friction & & specific gravity \\
\hline L .L & liquid limit & O.M.C & optimum moisture content; \\
\hline $\mathrm{C}_{\mathrm{v}}$ & Coefficient of consolidation, & & cohesion of soil, $\mathrm{kg} / \mathrm{cm}^{2}$ \\
\hline & $\mathrm{cm}^{2} / \mathrm{sec}$ & P.L & plastic limit \\
\hline Mv & coefficient of volume change & P.I & plasticity index \\
\hline & $\mathrm{cm}^{2} / \mathrm{kg}$ & S.L & shrinkage limit \\
\hline $\mathrm{k}_{\mathrm{v}}$ & $\begin{array}{l}\text { coefficient of permeability at } \\
\text { vertical direction, } \mathrm{cm} / \mathrm{sec}\end{array}$ & F.S. & free swelling \\
\hline
\end{tabular}




\section{INTRODUCTION}

Many researches were carried out to study the effect of liquid waste on the physical and mechanical properties of cohesive soils. However, few researches were carried out on the effect of liquid waste produced from sugar industries on properties. Effect of waste water on fine grained soil was studied by kirvo [1], in connection with the change of deformation properties of a clay paste under the action of detergents. $\mathrm{He}$ mentioned that, the main source of organic matter in soil is waste water (domestic or industrial waste water) because it contains many constituents. Shekhtman et al. [2] studied the deformation in a chemical - water treatment (cwt) plant of a large power station in "Ukraine" due to the seepage of acids, alkaline solutions and other minerals to the soil under the plant. They studied the deformation in the period from 1984 through 1989 where structures of the internal partitions in some rows were subjected to deformation associated with non uniform foundation settlement. They suggested that water insulating layers of impermeable durable materials, resistant to chemical reagents, must be placed during the installation of floors. Isaev et al. [3] studied the raising of a number of columns by $340-520 \mathrm{~mm}$ during operation of a plant. They studied the properties of soil after exposure to thermo phosphoric acid and found that swelling occurred due to leakage which led to wetting of the soil underlying the foundations with concentrated phosphoric acid. (TPA). They found that the swelling occur due to damaging leakages led to wetting of the bed soils of the foundations with concentrated phosphoric acid $\left(\mathrm{H}_{3} \mathrm{po}_{4}\right)$. Sakalovich [4] studied heaving of sandy bed by exposure to industrial liquid waste comprising sodium hydroxide and ammonium chloride solutions. The heaving caused dangerous situation in the main frame of a sugar refinery in Moscow. Crowford and Burn [5] studied large settlement of the Sinai Hospital buildings due to diffusing waste water in the soil under the foundations causing increasing of organic matter content and subsequently, change of the soil goechemical properties. Rehabilitation of the buildings from cracks and renovation of foundation damage at some parts of the hospital buildings were to be carried out. Holden, Page and Short [6] studied the cracks and settlement and their remediation in many important old buildings in southeastern of London. They mentioned that the problems of these buildings were associated with the diffusion of sea water and waste water in the soil under the building foundations. They noted that, more attention must be given to foundation and sub base of soil to protect the building from damages, cracks and failures. Robersts et al. [7] studied the reasons of building failures at Indiana Region, USA. They found that the main reason was inconvenient durability of soil under foundations due to the effect of chemicals on soil. The main source of chemical wastes and organic material was industrial waste water and domestic waste water. El-Kasaby et al. [8] studied the effect of organic matter and chemical constituents on the engineering properties and bearing capacity of sub- base soil under the foundation of the new Kafr Shoker Hospital. They found that geotechnical properties and bearing capacity of soil were changed to the worst. Kumaply and Ishola [9] studied the effect of caustic soda contamination on the strength and consistency limits of soil. They found that the increase of caustic soda contamination generally causes decrease in the liquid limit of the soil. This decrease was a reflection that the soil samples became more friable with increasing concentration of caustic soda contamination. Abdel Rahman et al. [10] studied the effect of organic matter content 
on the plasticity index and specific gravity of clayey soils. It was found that the plasticity index increased with the increase of the organic content. Statistical regression analysis was carried out and an exponential relationship was obtained and is expressed by; $I_{p}=a e^{b x}$. Also, it was found that the specific gravity increased as the organic content decreased. A hyperbolic relationship was obtained given by:

by; $\mathbf{G s}=\frac{x}{(a+b x)}$. Where $\mathrm{x}=$ organic content percentage, $\mathrm{a}, \mathrm{b}$ are constants corresponding to soil characteristics.

Srivastana et al. [11] studied the interaction behavior of a typical alluvial soil found in the plains of northern India contaminated by waste water discharged from four industries: sugar mill, paper mill, fertilizer plant and a power generation equipment manufacturing industry. In general, there was an increase in liquid and plastic limits of soil. The soil is most effected by paper mill waste water and least effected by sugar mill waste water. The maximum change in liquid limit was $37.9 \%$ and minimum was $7.9 \%$. As compared with liquid limit, the change in plastic limit was magnificent; the maximum change was $30.5 \%$ and minimum change was $12.5 \%$. The maximum decrease in shear strength is on the order of $434 \%$. It was marginal in case of sugar mill waste water. The coefficient of compressibility increased in all cases. ElSakhawy et al. [12] studied the effect of liquor on the physico-chemical properties of soil. They found that immersing the soil in black or white liquor changes its plasticity characteristics. The compressibility, strength and permeability of the clay may also be expected to change. El-Kasaby et al. [13] studied the effect of waste water on the behavior of fine grained soil and its change with time. It was concluded that O.M.C, $\mathrm{k}_{\mathrm{v}}$, F. $\mathrm{S}_{\text {. }}, \mathrm{C}_{\mathrm{c}}, \mathrm{S}_{\mathrm{c}}, \mathrm{m}_{\mathrm{v}}$ and $\mathrm{C}_{\mathrm{v}}$ increased with increasing the amount of waste water at applied pressure equal to or higher than $4.0 \mathrm{~kg} / \mathrm{cm}^{2}$. However, with increasing the amount of waste water $\gamma_{\text {max }}$ and C decreased. Ramadan et al. [14] studied the effect of oil contamination on physical and mechanical properties of clayey soil. They found that Atterberg limits increase with the increase of the contaminant. This increase was significant with oil of low viscosity. The changes were considerable with soil of high plasticity. The apparent cohesion of soil increases with the increase of the contaminant content. With oil of low viscosity, the increase of cohesion is high. The oil contamination increased $\left(\mathrm{C}_{\mathrm{v}}\right)$ for medium and high plasticity clay and increased $\left(\mathrm{m}_{\mathrm{v}}\right)$ of soil of high plasticity and slightly decreased it for soil of medium plasticity. El Sharif [15] studied the effect of black mazzot on the physical and mechanical properties of clayey soil. He concluded that, the $\left(\gamma_{\mathrm{dmax}}\right)$ of clay decreased with increasing black mazzot content to $6 \%$, then it increased.(O.M.C )decreased by increasing the mazzot content to $10 \%$ and $15 \%$ in clay soils. Liquid and plastic limits increased by increasing mazzot content to $15 \%$ permeability decreased by increasing mazzot content to $15 \%$, then it rapidly decreased and approached zero with mazzot content $\geq 17 \%$. Bayoumi [16] studied contamination of soil and its effect on its engineering properties .The study was limited to an experimental investigation of the effect of the change in pore fluid chemistry as a consequence of soil contamination on shear strength and consolidation of clay. The shear strength and consolidation characteristics were determined for both the reference samples mixed with several concentrations of deferent chemicals. He found that an increase in the concentration of such inorganic 
chemicals as $\mathrm{CaCO}_{3}$ and $\mathrm{Mg} \mathrm{SO}_{4}$ in the pore fluid reduced the shear strength of clay and increased its consolidation settlement. Increase in the organic content, using the raw sewage as a pore fluid, also reduced the shear strength of clay and increased its consolidation settlement increase in the length of the exposure time led to a significant decrease in the shear strength of clay.

\section{EXPERIMENTAL WORK}

The effect of the Liquid industrial waste resulting from molasses desugarization (LIWMD) at refinement factories on the physical and mechanical properties of cohesive soil was studied. Tests were performed by mixing cohesive soil with different amounts of the (LIWMD) ( $0,5 \%, 10 \%, 15 \%, 20 \%$ and $25 \%)$ by weight of dry soil. The properties of clay soil include: Atterberg limits, free swelling, compaction characteristics, shear strength parameters and consolidation behavior.

\subsection{Site investigation}

The investigated site is about $60 \times 70 \mathrm{~m}$ located at a refinement factory (factory of the Egyptian sugar \& integrated industries company) which is located at Hawamdea city in Giza governorate. This site is about 0.75 kilometers from the river Nile. Two boreholes were taken at different locations with $15 \mathrm{~m}$ depth .The results of laboratory tests were carried out on the extracted samples from the executed bores. Fine grained soil was taken from borehole No 1, at depth $2 \mathrm{~m}$. It consists of $42 \%$ clay, $56 \%$ silt and $2 \%$ sand. It is thus classified as clayey silt. Fig (2.1) shows particle size distribution curve. Fine soil has the following properties L.L $=61.6 \%, P . L=33.1 \%$ and $\mathrm{G}_{\mathrm{s}}=2.61$. Also, according to the unified soil classification system using the plasticity chart, the soil can be classified as high plasticity clayey silt as shown in Fig. (2.2).

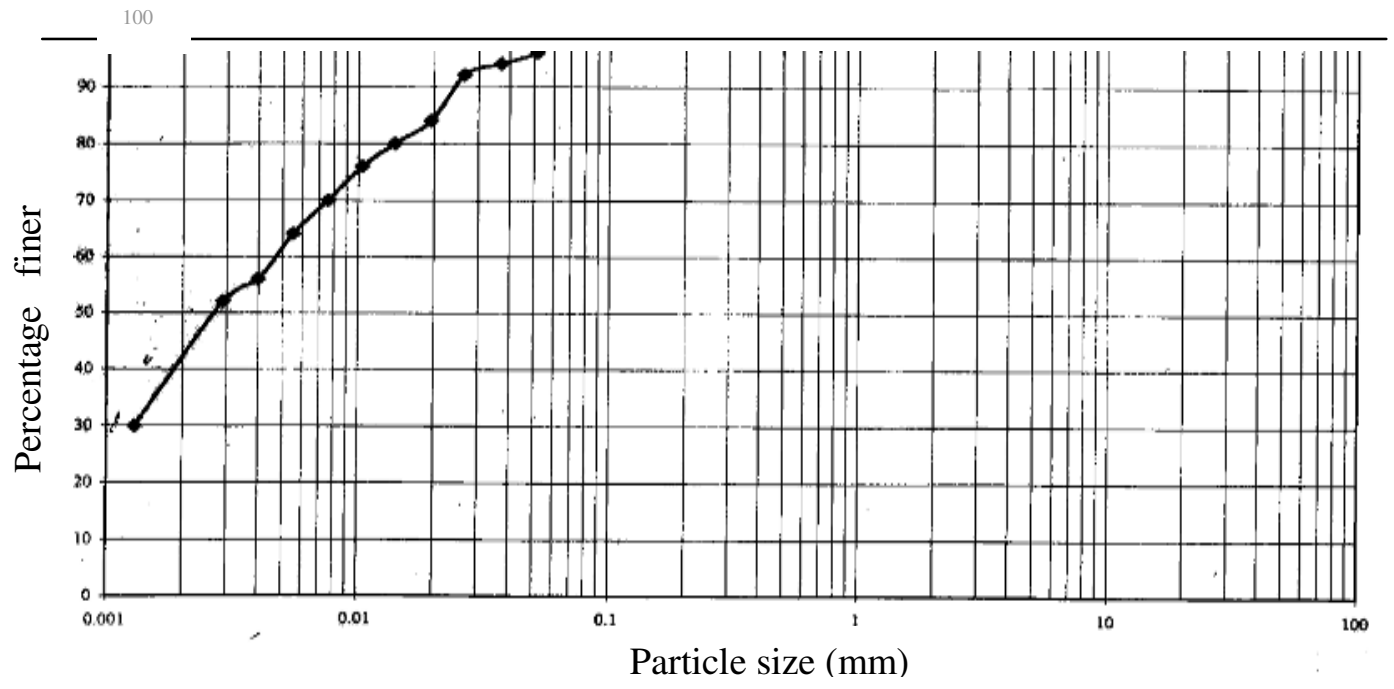

Fig. (2.1) Particle-size distribution 


\section{Plasticity}

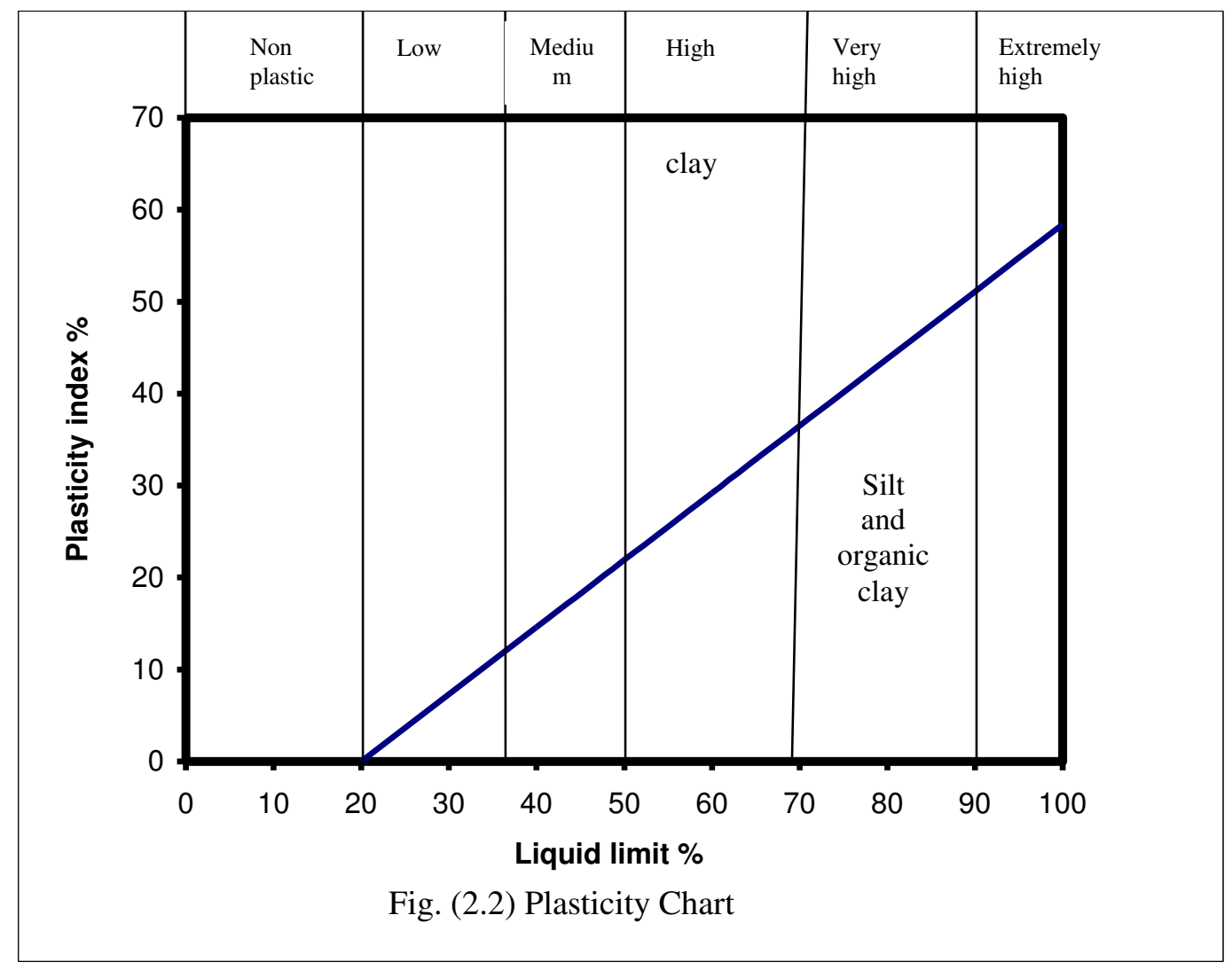

The complete chemical analysis of the soil is given in Table (2.1)

Table (2.1) Chemical analyses of the tested soil

\begin{tabular}{|l|l|l|l|l|l|l|l|l|l|l|}
\hline $\mathrm{SiO}_{2}$ & $\mathrm{Al}_{2} \mathrm{O}_{3}$ & $\mathrm{Fe}_{2} \mathrm{O}_{3}$ & $\mathrm{CaO}$ & $\mathrm{MgO}$ & $\mathrm{SO}_{3}$ & $\mathrm{Na}_{2} \mathrm{O}$ & $\mathrm{K}_{2} \mathrm{O}$ & $\mathrm{TiO}_{2}$ & $\mathrm{P}_{2} \mathrm{O}_{5}$ & L.O.I \\
\hline 46 & 15.54 & 12.04 & 5.3 & 2.60 & 0.1 & 0.74 & 0.92 & 2.18 & 0.92 & 13.00 \\
\hline
\end{tabular}

\subsection{Tested Materials and Test Procedure}

The materials used in this paper include:

\subsubsection{Brown Clayey Silt}

Natural soil weighting about $120 \mathrm{kgs}$ was brought from site to the soil mechanics laboratory, then, the soils were air dried, broken down and grinded using a big grinding machine. The soil was sieved on sieve No 36. The soil passing through sieve No 36 was again oven dried at a constant temperature of $105-110^{\circ} \mathrm{C}$ 


\subsubsection{Industrial Waste Liquid from Molasses Desugarization Project (Liwmd)}

Industrial waste liquid was brought from sugar refinement factory and taken from the pipe entrance to the treatment plant. About 60 liters of the (LIWMD) were brought directly in plastic containers in order to mix with dry soil for preparing the studied soil samples. Two samples from the (LIWMD) were taken to chemical analysis laboratories, in order to evaluate its physico-chemical properties and the remains kept in fridge. Table (2.2) shows the physico-chemical composition of the two samples. The first sample was tested fresh and the other sample after being kept for 15 months. The tests and results of the two samples were obtained from statistical analysis by geo chemical consultants and contest laboratory for quality control, respectively.

Table (2.2)

\begin{tabular}{|c|c|c|c|c|}
\hline S.N. & Parameter & Sample \# 1 & Sample \# 2 & $\begin{array}{c}\text { Decree } \\
\text { No. } 44 / 2000\end{array}$ \\
\hline 01 & Color & Dark Yellow & Greenish black & Non \\
\hline 02 & Chlorine $\left(\mathrm{Cl}_{2}\right) . \mathrm{m} \mathrm{g} / 1$ & ----- & $\begin{array}{ll}----- \\
\end{array}$ & 10 \\
\hline 03 & $\mathrm{pH}$ - value & 2.6 & 7.92 & $6-9.5$ \\
\hline 04 & Oil \& Grease , mg /1 & 82 & 66 & 100 \\
\hline 05 & B. O.D $-5 \mathrm{mg} / 1$ & 4197 & 4228 & 600 \\
\hline 06 & C.O.D.m g / & 8825 & 8503 & 1100 \\
\hline 07 & Suspended solids , mg /l & 246 & 401 & 800 \\
\hline 08 & Organic Matters mg /l & 1706 & 4116 & --- \\
\hline 09 & Settle able solids . $30 \mathrm{cc} / 1$ & 3.11 & 11 & 15 \\
\hline 10 & 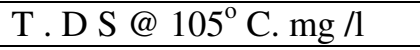 & 4241 & 1350 & $\begin{array}{c}-- \\
\end{array}$ \\
\hline 11 & Sodium ( $\mathrm{Na}$ ) mg/l & 214 & 380 & --- \\
\hline 12 & Potassium ( K) mg / 1 & 32 & 52 & -- \\
\hline 13 & Calcium ( Ca). m g / 1 & 43 & 147 & -- \\
\hline 14 & Magnesium (Mg ) . m g / 1 & 19 & 218 & -- \\
\hline 15 & Chloride $(\mathrm{Cl}) \mathrm{mg} / \mathrm{l}$ & 161 & 3956 & -- \\
\hline 16 & Bicarbon . $\left(\mathrm{HCO}_{3}\right) \mathrm{m} \mathrm{g} / \mathrm{l}$ & 0 & 877 & -- \\
\hline 17 & Sulphate $\left(\mathrm{SO}_{4}\right) \mathrm{mg} / \mathrm{l}$ & 1758 & 596 & -- \\
\hline 18 & Phoshate $\left(\mathrm{PO}_{4}\right) \mathrm{mg} / \mathrm{l}$ & 18.22 & 20.03 & 25 \\
\hline 19 & Silica $\left(\mathrm{SiO}_{2}\right) \mathrm{mg} / \mathrm{l}$ & 13.89 & 12 & -- \\
\hline 20 & Sulphide ( S) mg /l & 4.56 & 0.81 & 10 \\
\hline 21 & Ammonia $-\mathrm{NH}_{3} \mathrm{mg} / \mathrm{l}$ & 67 & 85 & --- \\
\hline 22 & Total Nitrogen . mg / & 173 & 189 & 100 \\
\hline 23 & Iron $(\mathrm{Fe})$ total $. \mathrm{mg} / \mathrm{l}$ & 6.85 & 6.18 & --- \\
\hline 24 & Manganese ( Mn ) mg /l & 0.68 & 0.13 & --- \\
\hline 25 & Total Heavy Metals . mg /1 & 3.02 & 0.99 & 5 \\
\hline
\end{tabular}

For preparing the tested soil samples to study the effect of (LIWMD) on the behavior of fine-grained soil, six-soil samples were mixed with different amounts of waste liquid $0.5 \%, 10 \%, 15 \%, 20 \%$ and $25 \%$ by weight of dry soil. Each soil sample was kept in a plastic container and stored in the soil mechanics laboratory at temperature $20^{\circ} \mathrm{C}$ 


\subsection{Testing Techniques}

The effect of the [IWLMD] at refinement factories on physical and mechanical properties of cohesive soil were studied. The tests were performed by mixing cohesive soil with different amounts of the [L I W M D] at zero time at $(0,5 \%, 10 \%, 15 \%$, $20 \%$ and $25 \%$ ) percentages by weight of dry soil . The properties of clay soil include: Atterberg limits, free swelling, compaction characteristics, shear strength parameters and consolidation behavior.

\subsection{Experimental Program of Physical and Mechanical Tests}

The physical and mechanical properties of the studied soil samples were determined according to the Egyptian code of soil mechanics and foundation design, part 2 [laboratory tests]. The tests are summarized as follows.

\subsubsection{Physical Properties Tests}

Liquid limit, plastic limit, shrinkage limit and free swelling for the soil samples 1 , $2,3,4,5$ and 6 were determined at zero time ( sample 1 is natural soil without waste).The free swelling tests were carried out also on the other soil samples from Kom-ombo city (in some bores at different depths ) in order to show the effect of the waste liquid on the swelling where this soil has high free swelling values.

\subsubsection{Mechanical Properties Tests}

For soil samples at zero time 1, 2, 3, 4, 5 and 6 all tests were carried out as:

\subsubsection{Compaction Test}

The compaction tests for the studied soil samples were carried out using the standard Proctor test (S P T).

\subsubsection{Direct Shear Test}

An untrained direct shear test using a strain - controlled shear box apparatus was adopted in this study to investigate the shear strength of the tested soil samples. The shear force and vertical displacement were measured .For each sample; the test was carried out four times under different normal stresses $0.5,1.0,1.5$, and $2.5 \mathrm{~kg} / \mathrm{cm}^{2}$, respectively.

\subsubsection{Consolidation Tests}

One consolidation apparatus (Odometer apparatus) was used in consolidation tests for the studied soil samples. In these tests, the specimens were loaded and soaked at 0.25 $\mathrm{kg} / \mathrm{cm}^{2}$ as overburden pressure, then, the applied pressure increments were $0.5,1.0$, $2.0,4.0$ and $8.0 \mathrm{~kg} / \mathrm{cm}^{2}$. The applied pressures were reduced to 4.0, 1.0, 0.5 and 0.0 $\mathrm{kg} / \mathrm{cm}^{2}$. 


\section{RESULTS AND DISCUSSION}

The influence of waste liquid on the physical and mechanical properties (Atterberg limits, free swelling, compaction characteristics, shear parameters and consolidation behavior) of fine-grained soil was investigated as following:

\subsection{Effect of Waste Liquid on Physical Properties of Soil Samples}

Different percentages of waste liquid were mixed with soil samples as $0,5 \%, 10 \%$, $15 \%, 20 \%, 20 \%$ and $25 \%$ of the weight of dry soil for each soil sample. The physical properties (liquid limit, plastic limit, shrinkage limit and free swelling) were determined and the effect is described as follows:

Figure (3.1) shows the relationship between liquid limit values and the waste liquid percentage of soil samples. It is clear that the liquid limit values decrease with increasing the percentage of waste liquid in soil samples. Fig (3.2) shows the relationship between plastic limit values versus the amount of waste liquid of tested soil samples and it can be seen that the plastic limit values slightly increase with increasing the amount of waste liquid in soil samples and this increase is relatively small.

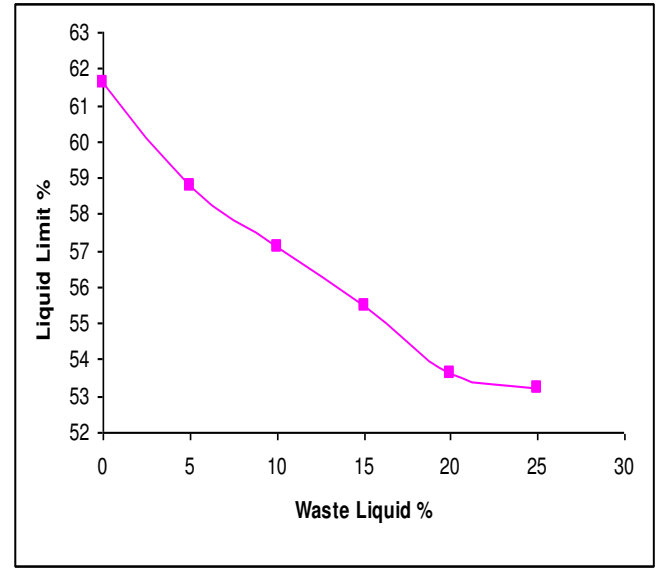

Fig (3.1) Effect of waste liquid on Liquid limit of soil

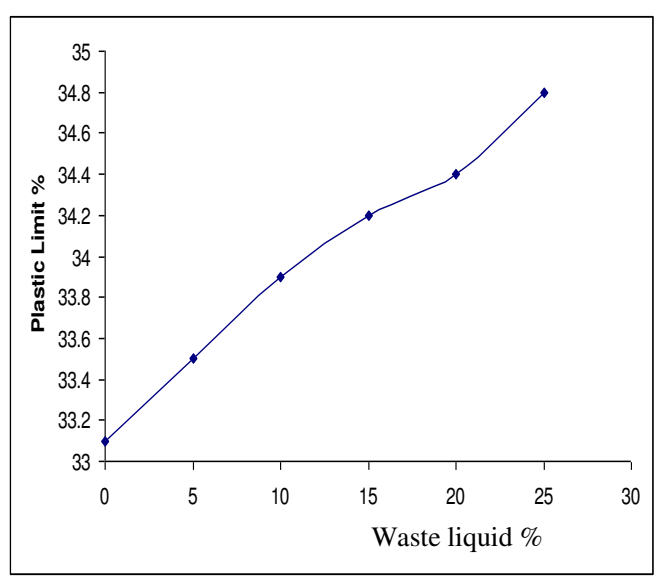

Fig (3.2) Effect of waste liquid on plastic limit of soil

The relationship of plasticity index versus the amount of waste liquid can be described in Fig (3.3) where the plasticity index greatly decreases with the amount of waste liquid in soil samples and this is associated with a decrease in the liquid limit values and a relative increase of plastic limit values.

Figure (3.4) indicates the shrinkage limit values versus the percentage of waste liquid in the soil samples and it can be noticed that the shrinkage limit values gently decrease with increasing the amount of waste liquid in soil samples until 15\% percentage. Then there is a sharp decrease with increasing the percentage from $15 \%$ to $20 \%$. After that, there is very small change. These changes of liquid limit, plastic limit, plasticity index and shrinkage limit values may be attributed to the chemical process between chemical constituent and soil particles 


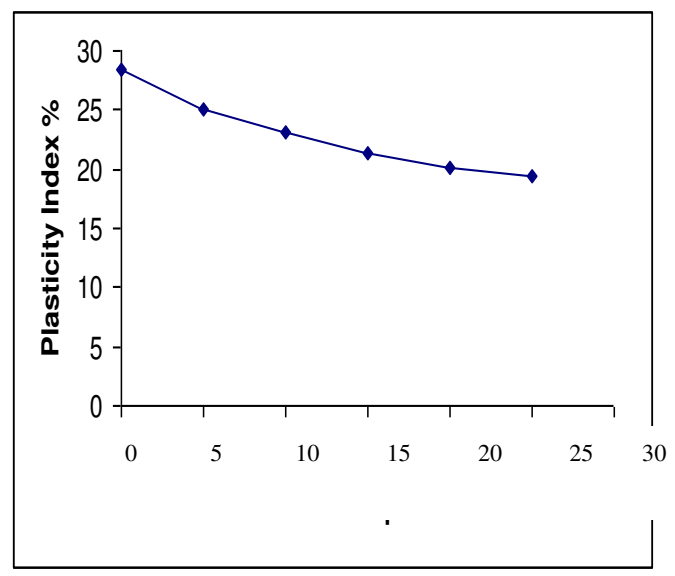

Fig. (3.3) Effect of waste liquid on plasticity index of soil

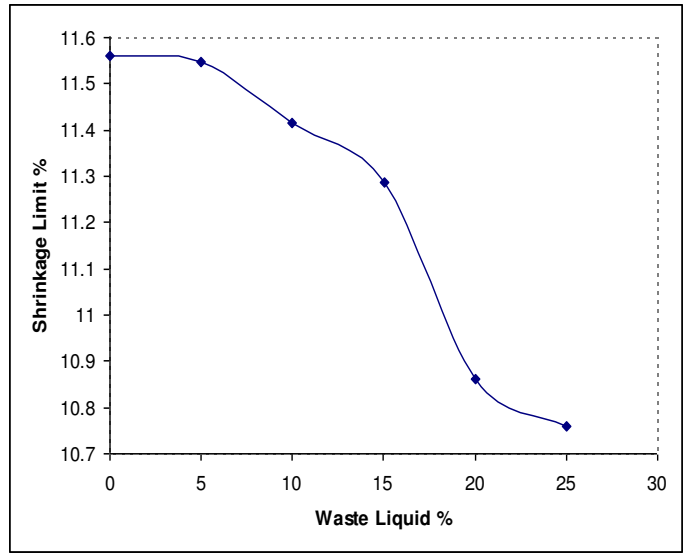

Fig (3-4) Effect of waste liquid on shrinkage limit of soil

The results of free swelling of soil samples from a refinement factory and at Kom-ombo city are shown in Fig. (3.5) and it is clear that the soil samples at the refinement factory are slightly affected by waste liquid with percentage $5 \%$, after that, there is no effect. But for soil at Kom-ombo city, free swell values decrease gradually with increasing the amount of waste liquid for all soil samples. Finally, it can be noticed that the effect of waste liquid on soil samples from site of desugarization project is very small. But there is a relatively significant effect on Kom-ombo soil samples where this soil has high free swelling values. This may be attributed to the increase of sodium composition in the (LIWMD)

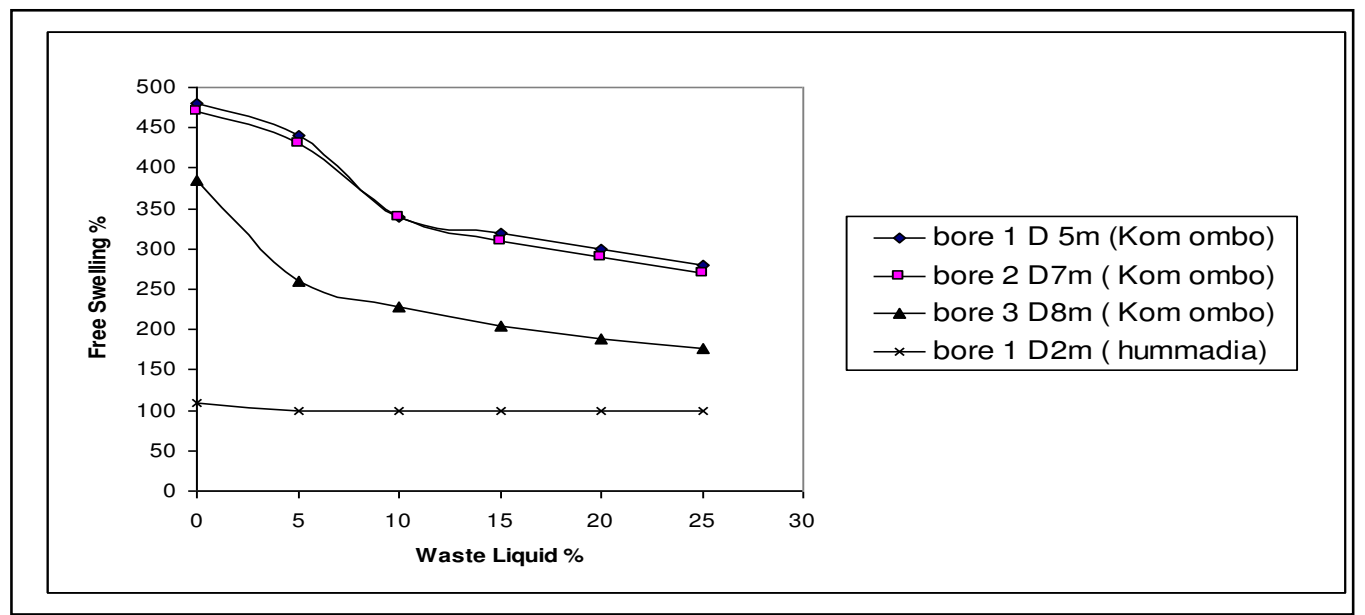

Fig. (3.5) Effect of waste liquid on the free swelling of soil at refinement factory in Hawamdea city and at Kom-ombo city 


\subsection{Effect of Waste Liquid on Mechanical Properties of Soil Samples}

Different percentages of waste liquid are mixed with soil samples as $0,5 \%, 10 \%, 15 \%$, $20 \%$ and $25 \%$ from weight of dry soil. The effect of waste liquid on the mechanical properties is described as follows

\subsubsection{Compaction characteristics:}

For each soil sample, the compaction results (maximum dry density and optimum moisture content) are determined. As shown in Fig. (3.6), it is evident that the maximum dry density slightly increases with increasing the amount of waste liquid in the soil samples until 15\%. After that, its values decrease with the increase percentage of waste liquid. As shown in Fig. (3.7), it is distinct that the optimum moisture content decreases gradually with the increase percentage of waste liquid in soil samples. Finally, the compaction results shown in Figs. (3.6) and (3.7) may be attributed to the development of flocculation phenomenon which increases as the electrolyte concentration increases.

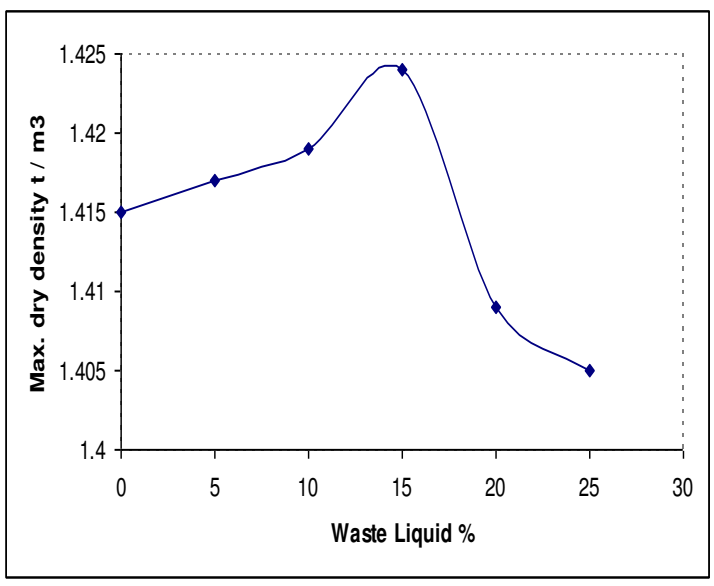

Fig. (3.6) Effect of waste liquid on the maximum dry density of soil

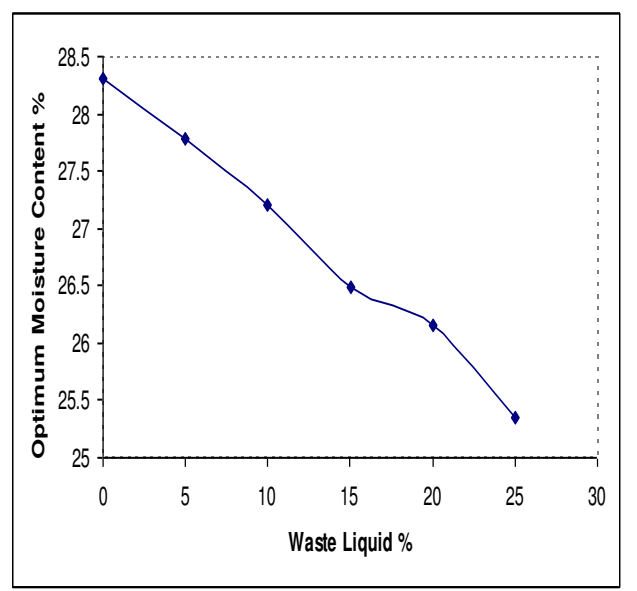

Fig. (3.7) Effect of waste liquid on the optimum moisture content of soil

\subsubsection{Effect of Waste Liquid on Shear Strength Parameters:}

Cohesion and angle of internal friction values for soil samples corresponding to different amounts of waste liquid are shown in Figs (3.8) and (3.9). It can be noticed that the decrease of cohesion and angle of internal friction occurs with increasing waste liquid to 5\%. Then, cohesion and angle of internal friction increase with increasing the amount of waste liquid until $15 \%$. After that, its values decrease with the increase in the percentage of waste liquid .These changes may be attributed to the increase in organic matter content. 


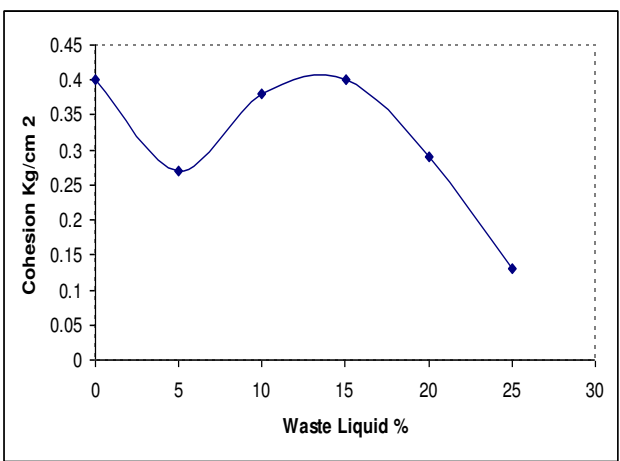

Fig. (3.8) Effect of waste liquid on the cohesion of soil

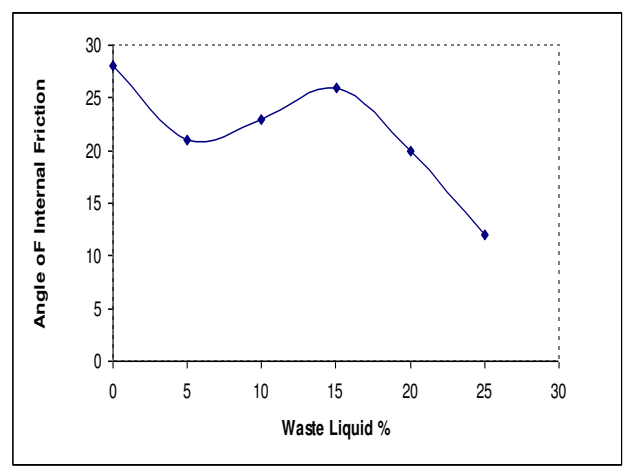

Fig. (3.9) Effect of waste liquid on the angle of internal friction of soil

\subsubsection{Effect of Waste Liquid on the Consolidation Behavior of Soil}

The consolidation test results (coefficient of consolidation, coefficient of volume change and coefficient of permeability at vertical direction ) for each applied stress increment at different amount of waste liquid are determined and plotted in Figs ( 3 . $10),(3.11$ ) and (3 . 12). Referring to Fig. (3.10), it appears that the coefficient of consolidation, $\mathrm{C}_{\mathrm{v}}$ values increase gradually with increasing the applied stresses at applied stress increments from 0.5 to $2 \mathrm{~kg} / \mathrm{cm}^{2}$ while at applied stress increments from 2 to $8 \mathrm{Kg} / \mathrm{cm}^{2}$, the $\mathrm{C}_{\mathrm{v}}$ values decrease gradually. The $\mathrm{C}_{\mathrm{v}}$ values decrease gradually with increasing the amount of (LIWMD). From Figs ( 3.11 ) and ( 3.12 ), it is clear that the coefficient of volume change, $\mathrm{m}_{\mathrm{v}}$ and coefficient of permeability at vertical direction, $\mathrm{K}_{\mathrm{V}}$ values decrease gradually with increasing the amount of waste liquid in soil sample at all applied stress increments. These results may be attributed to the increase of organic matter content or increase of elemental composition in the [LIWMD].

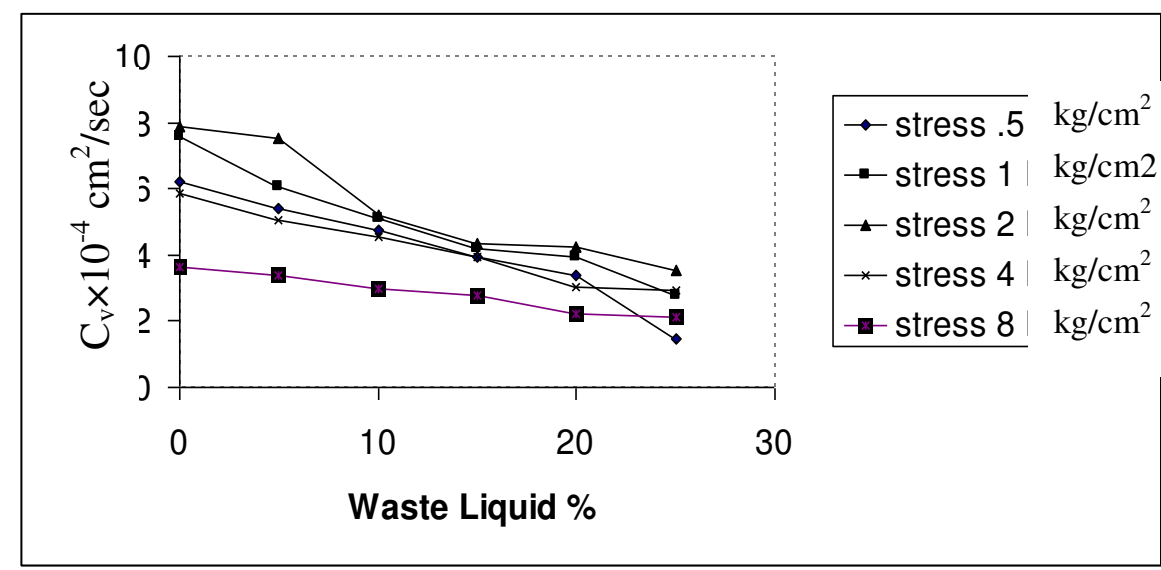

Fig (3.10) Effect of waste liquid on the coefficient of consolidation of soil with $\mathrm{G}$ different applied stresses 


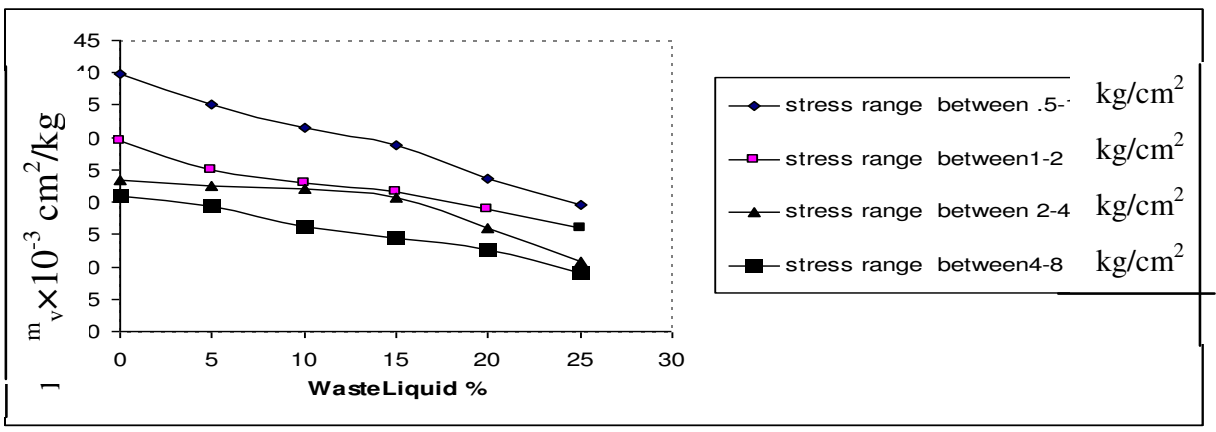

Fig.(3.11): Effect of waste liquid on the coefficient of volume change of soil with different applied stresses range

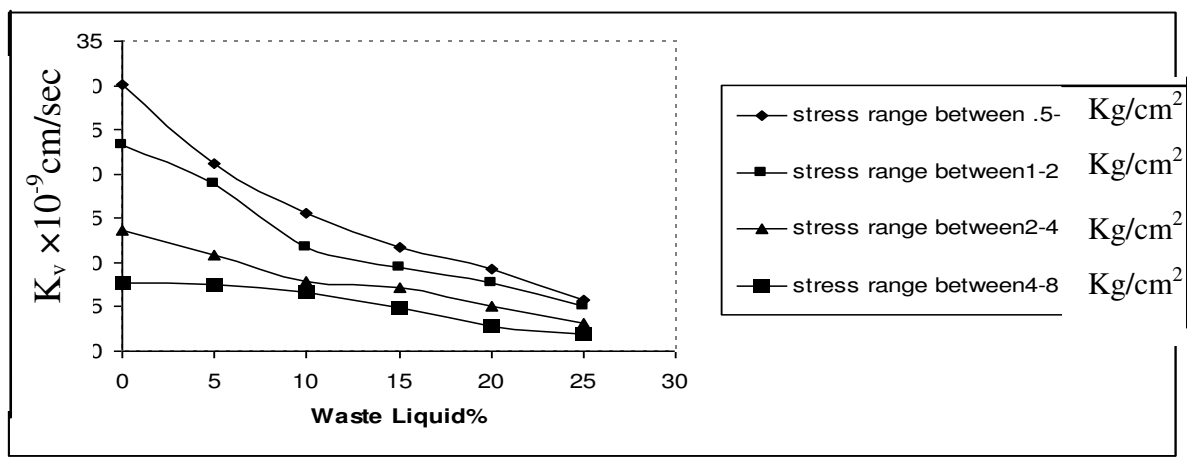

Fig (3.12): Effect of waste liquid on the coefficient of permeability at vertical direction of soil with different stresses range.

\subsubsection{Effect of the Chemicals Component of [ Liwmd ] on the Physical and Mechanics Properties}

Due to the presence of positive charges of $\left(\mathrm{Na}^{+}, \mathrm{Ca}^{+2}, \mathrm{Mg}^{+2}, \mathrm{k}^{+}, \mathrm{NH}_{4}^{+}\right)$in the liquid waste that react with the negative charges of $\left(\mathrm{CL}^{-}, \mathrm{SO}_{4}^{-}\right)$in the clay particles to form a binder materials which improvemes the physical and mechanics properties of the clay soil in all percentage ratio except the values of maximum dry density, cohesion and angle of internal friction which decrease with the increase of the percentage of liquid waste beyond $15 \%$. This may be attributed to the development of flocculation phenomenon which increases as the electrolyte concentration increases.

\section{CONCLUSIONS}

Based on the analysis and discussion of the test results concerning the effect of industrial waste liquid from molasses desugarization project (LIWMD) at refinement factories on cohesive soil properties, the following general conclusions can be drawn:

- The increase in (LIWMD) amount led to decrease in liquid limit, plasticity index and shrinkage limit values but a slight increase in plastic limit values.

- There is very small effect from (LIWMD) contamination on the free swelling of soil from the site of molasses desugarization plant but there is a relatively significant effect on Kom-ombo soil 
- A Slightly increase occurs in the maximum dry density until $15 \%$. After that, its values decreases with the increase of the percentage of [LIWMD] and a gradual decrease occurs in optimum moisture content with increasing the amount of (LIWMD)

- A decrease occur in both cohesion and angle of internal friction when increasing (LIWMD) to $5 \%$ percentage, then, its values increase with increasing (LIWMD) until $15 \%$ percentage. After that, its values decrease with increasing the percentage of (LIWMD)

- Coefficient of consolidation, $\mathrm{C}_{\mathrm{v}}$ values increase gradually with increasing the applied stress increments from 0.5 to $2 \mathrm{~kg} / \mathrm{cm}^{2}$ while at applied stress increments from 2 to $8 \mathrm{~kg} / \mathrm{cm}^{2}$, the $C_{v}$ values decrease gradually . The $\mathrm{C}_{\mathrm{v}}$ values decrease gradually with increasing the amount of (LIWMD).

- Coefficient of volume change, $\mathrm{m}_{\mathrm{v}}$, and coefficient of permeability at vertical direction, $K_{v}$, values decrease gradually with increasing the amount of (LIWMD) for all applied stresses.

- The presence of positive charges in the liquid waste react with the negative charges in the clay particles forming a binder materials which improvemes the physical properties and consolidation behavior .

- Shear strength $(\mathrm{C}, \phi)$ parameters and compaction characteristics changed to worst with the increase of the percentage of liquid waste beyond $15 \%$ because the increase of electrolyte concentration leads to the development of flocculation phenomenon.

\section{REFERENCE}

1- Kirvo, B. (1989): " Influence of waste on soil deformation". proc. $12^{\text {th }}$ inter. conf.on soil Mech . and found. Eng., Rio de Janeiro, vol.3pp 1881-1882.

2- L.M. Shekhtmon , v.T. Baranov, and G.F. Nesterenko (1995) . "Building deformation caused by the leak age of chemical reagents. "Soil Mech and found. Eng, vol 32, No 1.pp 32-36.

3- B.N. Isaev. N.N Tropkova, S.Yu . Badeen and V.B. Balatsku. ( 1995) " Protecting the bed soil of foundation from damaging wetting by acids ". Soil. Mech and found .Eng, Vol 32, No4. pp130-134.

4- V.E. sokolovich . ( 1995 ) " Chemical heaving of soil " J. soil Mech. and found . Eng. vol32, No 4 . pp135 - 137.

5- Growford , C.B. and Burn , K. N .( 1992) : " settlement studies on the Mt. sinai Hospital " . Journal of Canada, attuma, vol. 345 , No. 22 .

6- Holden, W. R. ,Page , C.L and Short , N.R. ( 1991 ): " Protection of aesthetic buildings at London" . Concrete Building Research, Ellis Horwood limited, London, pp. 143 - 155.

7- Roberts, M.H; Roy, D. M . and Kumar ( 1990 ): " Failure of Building foundation on clay " Proc. ASCE, Vol. 217 , pp.853-859.

8- El-Kasaby E.A and El- Saadany , M . M . ( 1993 ) " Effect of circumstances surrounding foundation on safety of construction " $5^{\text {th }}$ Arab conf. on struc. Eng, civil Eng. Dept; Al-Fateh univ. Tripoli, Lybia, vol. 2, pp1255-1266 . 
9- Kumaply, N. K and Ishola, A .(1985) "The effect of chemical contamination on soil strength. " Proceedings of the $11^{\text {th }}$ international conference on soil Mech. and foundation Engineering, San Francisco, U.S.A., pp.1199- 1201.

10- Abdel- Rahman, A.; Mazen, S. a . and EL-Demery , M .G. (1986) . " Influence of organic content on some engineering properties of clayey soil, " Journal of Egyptian S.S.M.F.E., vol . 1,pp.17-19 .

11- Srivastana , R.K.; singh, M. and Tlwasi , R.P.(1994) " Laboratory study of soil industrial waste water interaction behavior ", proceedings of the Delhi, India , pp. 1553-1556.

12- EL-Sakhawy . R . R. ; Shater, M.;Abou El-Ainain, S.and Zeidan, S.(1994)."The Effect of liquid on the physico-chemical properties of soil , "Alexandria conf. on structural and Geot.Eng., 18-20 April , pp. $137-145$.

13- El- Kasaby E. A and EL-Saadany and Alnos . A. E ( 1994) " The effect of waste water on the behavior of fine- grained soil " . M.sc. thesis, Banha Higher Institute of Technology .

14- Ramadan , E.H.; Taha, Y.K. and Kenawi . M.A.(1997)," Effect of oil contamination on physical properties and shear strength of clayey soil - a case study", proceedings of Al- Azhar Engineering Fifth international conference , Cairo, Egypt , vol .4. pp. 294- 306

15- El - Sharif, M.A , ( 1999) " The Effect of black mazzot on the physico mechanical and chemical properties of soil " Bulletin of the faculty of Engeneering Assuit univ. , vol. 27, No. 1pp.15-23.

16- Bayoumi , S.A., ( 1994) : " Geo- environmental compatibility of clay liners ' ph.D.thesis, faculty of Eng. Zagazig univ.

\section{تأثير مخلفات الصرف الصناعى السائلة الناتجة من مشروع استخلاص السكر من

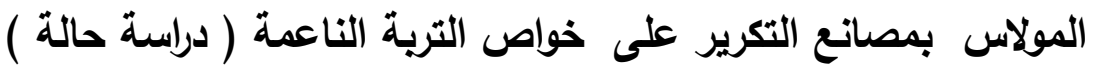

ينتج عن تشغيل مشروع استخلاص السكر من المولاس بمصانع التكرير مخلفات صرف سائلة (فيناس مخفف) يمر خلال خط انحدار مكون من مواسبر فخار ومطابق خرسانية الى محطة الرفع حيث ينت

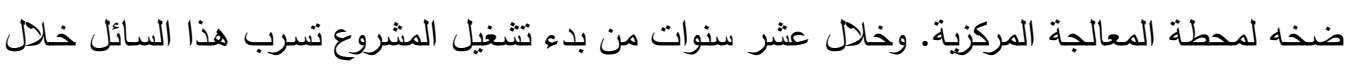

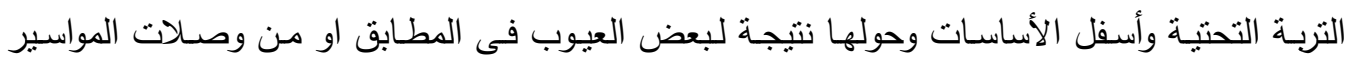
الحاملة ونتج عن ذلك مشاكل عديدة فى الطريق المجاور وفى التربة التحتية .

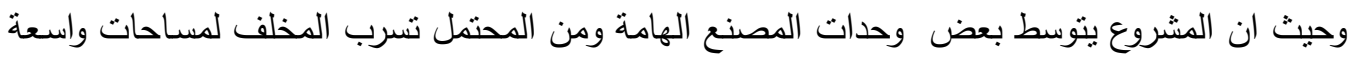
وبأعماق كبيره فى التربة. لذا فقد تم أخذ عينات من التربة الموجوده بموقع المصنع وبن وبالقرب من أماكن هذه المواسير والمطابق وكذلك تم أخذ كمية من مخلفات الصرف السائلة وتم نقلهما لمعامل ميكانيكا

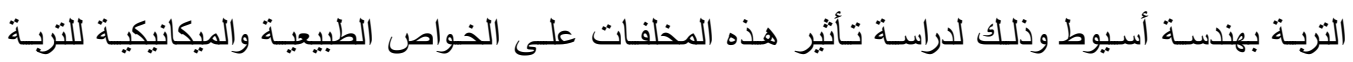
الناعمة. وقد تم تحديد هذه الخواص قبل وبعد إضافة المخلفات للتربة. 
ومن هذه الدراسـة أمكن التوصل لبعض من النتائج الهامة والتى من أهمها أن قوة تماسك التربـة وزاوبية الاحتكاك الداخلى ثقل بزيادة نسبة المخلف السائل بعد نسبة 15 \% . وكذلك معاملات التصلد والتغير الحجمى والنفاذية تقل بزيادة نسبة المخلف. كما يحتوى البحث على العديد من النتائج الهامة الاخرى . 